\title{
FACTORS FACILITATING TEACHER'S PROFESSIONAL COMPETENCE DEVELOPMENT
}

\author{
Alyona SHYBA* \\ Yuriy Fedkovych Chernivtsi National University, Ukraine
}

\begin{abstract}
The objective of the article is to further study the concept "teacher's professional competence” as well the ways of its formation. The research was conducted among the students as prospective teachers, and teaching staff of Yuriy Fedkovych Chernivtsi National University. The analysis of the research helped prove the essential role of some factors in the professional development of future teachers. In particular, such factors as knowledge of the teaching subject, knowledge of effective teaching methods and skills to implement them, the importance of teaching practice, the personality factor, teacher's self-education were singled out. Therefore, the paper aims to outline a few ideas on how to ensure the implementation of the above-mentioned considerations. We also dwell upon the impact of the human behavior on the process of foreign language learning and teaching. That is why knowledge about affective factors is consequential in the academic process and using some interactive methods can also help lower the affective filter. Types of motivation and ways to enhance it are described in the paper too.
\end{abstract}

Keywords: competence, teacher's professional competence, interactive language teaching, motivation

\section{INTRODUCTION}

The higher education reform which started in 2014 in Ukraine, aiming at meeting common European standards for higher education, put forward new demands on teachers and therefore on the way they were trained. The function of the teacher has changed immensely, and it has now become something more than delivering knowledge or lecturing. The teacher is not merely an instructor, but a person who guides, facilitates and supports students. The main stress is on making the students active and shifting from an instructivist approach to a constructivist one, which is learner-centered and focuses on making students

\footnotetext{
*alyonashyba@ukr.net
} 
active participants in the academic process and on playing a more important role in the process of foreign language acquisition. The importance of interaction in FL acquisition is obvious, and that is why collaborative learning is encouraged.

Constant changes in society as well as the quick development of technology influence all aspects of human life and the teaching process in particular. Computers are now not only a source of information, but also a tool for teachers to enhance their lessons, making the students more interested, and therefore more motivated.

Thus, meeting the challenges of the time, teachers have to perform more and more functions. They have to be competent not only in the subject they teach, but also have deep knowledge in various sciences, be familiar with modern technologies and use them in the classroom, know and follow the main principles of teaching, types of motivation and their sources, etc. Still, the main task of the teacher is not limited to teaching the language, as it also involves making their students think critically, analyze, formulate conclusions, and further their own development. This is why the teacher's professional competence is the subject of research for many scholars today.

The aim of the article is to define the teacher's professional competence and to study the factors that facilitate its formation.

To conduct the research a number of methods have been used: theoretical - survey, analysis and summary of the literature, and empirical methods - observation, testing, questioning, and studying the results of the academic process.

\section{PROFESSIONAL COMPETENCE}

The question of competence has always been vital for humanity. But the term "professional competence" in the context of pedagogy first appeared in the second half of the previous century and stood to describe a broader notion than a habit and a skill (as it includes knowledge, skills, and attitudes). Still, there is no unanimity among scholars up to now concerning the definition of the term.

Speaking generally, a competent person is said to be one who "acts responsibly and effectively according to given standards of performance" (Mulder 109). A very precise definition of competence is given by Deakin Crick, who writes that it is "a complex combination of knowledge, skills, understanding, values, attitudes and desire which lead to effective, embodied human action in the world, in a particular domain” (Deakin Crick 38).

Dergunova describes the process of formation of professional competence as "a managed process of becoming a professional by means of education and self-education” (Dergunova 22).

European Ministers of Education agree on the fact that "to be fully effective in teaching, and capable of adjusting to the evolving needs of learners 
in a world of rapid social, cultural, economic and technological change, teachers themselves need to reflect on their own learning requirements in the context of their particular school environment, and to take greater responsibility for their own lifelong learning as a means of updating and developing their own knowledge and skills” (Caena 7).

As the teacher's qualification is essential in the academic process, his/her professional competence is the main concern of pedagogy. Researcher Maria Liakopoulou of Aristotle University of Thessaloniki singles out the following groups of characteristics a competent teacher should possess: personality traits, attitudes and beliefs; pedagogical skills and knowledge, which include subject knowledge, knowledge of learners, general pedagogy, teaching methodology, curriculum knowledge, knowledge of contexts and knowledge of self (Liakopoulou 68-69).

In the present paper the foreign language teacher's professional competence is defined as a broad, multifaceted, integral concept, which determines the degree of mastery of the profession, is manifested in the adequacy of solving professional tasks in the sphere of foreign language teaching.

\section{FACTORS THAT FACILITATE THE FORMATION OF A TEACHER'S PROFESSIONAL COMPETENCE}

Learning foreign languages nowadays is of extreme importance as a factor of active communication among people both in the process of manufacturing and that of education. Consequently, the process of future teachers training should also receive due attention. In the list of competences the teacher should possess, according to the European Commission, are the ones which require profound knowledge of the subject a specialist is going to teach, and the necessary pedagogical skills to teach it. Of no less importance is the need to promote some key professional values and attitudes among teachers like reflective practice, autonomous learning, engagement in research and innovation, collaboration with colleagues and parents, and an involvement in the development of the whole school." (Caena 8-9)

We wanted to find out how effectively the process of competence formation is conducted in Chernivtsi National University, to single out the difficulties the academic staff faces during this process, and to suggest some solutions, so we applied some empirical methods: pedagogical observation, discussions, questionnaires, testing, and studying the results of the learning activity.

A deep survey and analysis of the literature on methodology as well as our own teaching experience helped single out certain factors which contribute to the effectiveness of the formation of our future teachers' professional 
competence. They include knowledge of teaching subject, knowledge of methods of TFL, teaching practice, personality factor, teacher's self-education.

In order to collect data we discussed the problem and used a questionnaire among 50 teaching staff, tenured professors, associate professors, and teachers of the Department of English and secondary schools. The first step to find out whether the hypothesis is confirmed was distributing the questionnaire among the academic teaching staff of the department.

Table 1 The results of the questionnaire for teachers

Q: Dear colleague! How important do you consider the contribution of the following factors to the success of a FL teacher?

\begin{tabular}{|l|l|l|l|}
\hline & Very important & Average & $\begin{array}{l}\text { Not very } \\
\text { important }\end{array}$ \\
\hline 1. Knowledge of teaching subject & $100 \%$ & - & - \\
\hline 2. Knowledge of methods of TFL & $86 \%$ & $14 \%$ & - \\
\hline 3. Teaching practice & $90 \%$ & $10 \%$ & - \\
\hline 4. Personality factor & $90 \%$ & $8 \%$ & $2 \%$ \\
\hline 5. Teacher's self-education & $98 \%$ & $2 \%$ & - \\
\hline Other factors (write if any): & $\begin{array}{l}\text { Communication skills; } \\
\text { Creativity; } \\
\text { Management and organizational skills. }\end{array}$ \\
\hline
\end{tabular}

The observation and data analysis revealed knowledge of the teaching subject is the priority mentioned by all the teachers questioned. $98 \%$ of respondents stress the importance of self-education. Speaking about the ways of teaching, the professors and teachers note that knowledge of FLT methods and teaching internship are very important, but practical application of knowledge of methods is of greater significance. Only $2 \%$ of respondents don't consider the personality factor to be very important for teaching, while $90 \%$ claim otherwise. Among other important factors teachers and professors mentioned communication skills, imagination and creativity, management and organizational skills, and a sense of humour.

The same questionnaire was given out to the students who receive teacher training. It was interesting to note that they have a somewhat different view as to the importance of the factors that make a good teacher. There were 60 respondents - MA and BA students. 
Table 2 The results of the questionnaire for students

Q: Dear student! How important do you consider the contribution of the following factors to the success of a FL teacher?

\begin{tabular}{|l|l|l|l|}
\hline & Very important & Average & $\begin{array}{l}\text { Not very } \\
\text { important }\end{array}$ \\
\hline 1. Knowledge of teaching subject & $100 \%$ & - & - \\
\hline 2. Knowledge of methods of TFL & $40 \%$ & $60 \%$ & - \\
\hline 3. Teaching practice & $70 \%$ & $30 \%$ & - \\
\hline 4. Personality factor & $90 \%$ & $10 \%$ & - \\
\hline 5. Teacher's self-education & $100 \%$ & - & - \\
\hline Other factors (write if any): & $\begin{array}{l}\text { Communicative competence; } \\
\text { Practice abroad. }\end{array}$ \\
\hline
\end{tabular}

Having compared the answers given by teachers and students, we can see that all the respondents agree on the fact that knowledge of the teaching subject and teacher self-education are the two most important factors that influence the development of a teacher's professional competence. Students also pay much attention to the personality factor (90\%).

The data analysis of the questionnaires reveals that students as well as their professors agree on the importance of the above-mentioned factors in professional development. They fully understand the importance of knowledge of the teaching subject and of self-education, but somewhat underestimate the importance of applying the gained knowledge in their teaching internship (only $70 \%$ of the students, and $90 \%$ of the teachers name it as a very important factor in professional development). Among other factors students also mention the communicative competence and add the importance of its improvement by going to language schools in English speaking countries.

My next step was to analyze the necessary conditions for the implementation of the abovementioned factors, which can secure effective organization of the academic process. The experiment aiming at studying the efficiency of interactive technologies in the academic process was conducted in Chernivtsi National University in 2013. The results of that research revealed that the introduction of interactive technologies lead to a higher number of students with a high level of professional competence in the target group (about $40 \%$ more than in the control group, students who had not been exposed to a variety of interactive technologies) (Shyba 194 - 95).

The role of interaction in the process of foreign language learning can hardly be overestimated, as it is not only about speaking and listening, but about a constant exchange of ideas and fruitful collaboration. Linguistic collaboration, as Wells put it, is "a collaborative activity involving the establishment of a 
triangular relationship between the sender, the receiver and the context of situation” (Wells 46-47).

It is essentially important that the process of study is interactive. The academic process, as defined by Goncharenko, is the system of organization of educational activities based on the unity and interrelation of teaching and learning, aiming at the achievement of instructional and educational goals (Goncharenko 276).

Aiming to find out the main sources of communication that students benefit from in this process, I asked them to rate the object of communication in the academic process according to their importance. The results were as follows:

1. Teacher during the lecture $-7 \%$

2. Teacher during a practical class $-24 \%$

3. Teacher out of the classroom (extra-curricular activity) $-4 \%$

4. Groupmates during the class $-13 \%$

5. Groupmates out of the classroom $-9 \%$

6. Computer as a means of instruction $-3 \%$

7. Computer as a source of information $-20 \%$

8. Book (manual, textbook, dictionary) $-14 \%$

9. Lecture notes $-6 \%$

The data analysis suggests the most frequent and most important types of students' interaction in the academic process are: teacher and student, I-netstudent, student-student and book-student. Regrettably, the computer as a means of instruction ranks last, and I believe this is what deserves special attention and what should be improved.

Pedagogical interaction, that between teacher and students, in the course of which the constructive, informative, communicative, organizational and affective functions of pedagogical education can be realized (Akhmad 6), is very important in the teaching/learning process. However, it should never be the only type of interaction during the class. We support Rivers's viewpoint that teacherdominated classrooms cannot be interactive. "Interaction can be two-way, threeway, or four-way, but never one-way” (Rivers 9).

Interactive language teaching creates favorable conditions for learning the language, for practicing future profession tasks. Interactive methods can ensure interesting and motivating classes, and orient the academic process on acquisition, rather than learning. According to one of Krashen's hypotheses, learning is less important than acquisition, which is very similar to the way a child acquires his/her mother tongue. And if speaking a foreign language fluently is the main goal of a teaching-learning process, then explicit teaching of rules should be substituted by a natural meaningful interaction. 
While teaching a communicative course we have noticed that the implementation of interactive methods (like brainstorming, jigsaw, debate, PRES etc.) creates favorable conditions for the above-mentioned factors of the development of professional competence. In particular, work in pairs, discussions, the "aquarium", and information gap foster communicative skills, all types of role play and simulation encourage practicing tasks related to a future profession, which helps acquire methodological competence in a natural way, as the time students spend directly participating in teaching is limited (a teaching practice starting from the 8-th semester only). Interactive foreign language learning gives students a chance to have more language practice; as they focus on the task, they are more involved in studying and eager to help each other.

Besides, interaction in the process of foreign language learning helps lower the affective filter, which makes students feel secure, less stressed and anxious, and so they improve their results. The most important personality factors that contribute to the success of foreign language acquisition are selfesteem, inhibition, risk-taking, anxiety and motivation.

Personal self-esteem is important in all aspects of human life, not only in learning. Any cognitive activity can hardly be carried out successfully without some degree of self-confidence. Usually, all mature people possess a certain level of general self-esteem, as a result of the accumulated life experience and the assessment of the world around them. Situational self-esteem in the context of second language learning is apparent in certain social situations. The third level - task self-esteem - happens when a person evaluates himself/herself while performing a particular task within specific situations (it can be a particular task during foreign language acquisition). Though it is hard to say whether selfesteem influences success in language learning or vice versa, the connection between them as well as the importance to work on both has been proved.

Anxiety and inhibition can also be typical in FLL as it is natural for a person to feel self-doubt or worry in a new situation or to build a "defense wall" against something unfamiliar. Excessive anxiety may hamper the process of language acquisition. Simulation and role play activities that we used with the students during communication classes proved to be very effective in lowering anxiety and inhibition, as students could experiment with their knowledge while interacting with others. They were also trained to deal with unpredictable communication or professional situations.

Inhibition is closely connected with risk-taking. Foreign language learning, especially at the beginning, is almost impossible without making mistakes, and students should not fear making them but rather take risks and speak, as this is the only way to make progress in FLL. According to Beebe's investigation, fossilization of certain patterns of error may be due to a lack of 
willingness to take risks (Beebe, 34). Students with a high level of self-esteem are more eager to take risks in learning.

All of the above-said makes allows us to conclude that the affective factors are interrelated and influence the process of foreign language learning and that of professional competence development. A natural and friendly language learning atmosphere creates favorable conditions to raise the students' self-esteem, to encourage them to take risks, and to lower their anxiety and inhibition. Cooperative learning helps share, encourage, and accept responsibility for one's own learning and that of others (Rivers 9), and it motivates students.

Motivation deserves special attention, as it is crucially important for foreign language learning and teaching, as well as for self-development.

Motivation is the first vital step in the process of language learning. Students must feel an interest and a desire to have interaction, notice new information and use a foreign language for communication. Motivation is related to one of the basic aspects of the human mind and behavior. It determines the direction and scope of human behavior or, in other words, the choice of a particular action, the persistence with it, and the effort expended on it (Zoltan 18).

Gardner singles out four aspects of motivation: a goal, effortful behavior, a desire to attain the goal and favourable attitudes toward the activity in question (Gardner 10-12). The learner's goal determines the type of motivation. Two general types of motivation are intrinsic and extrinsic. If the learner's goal is to study in order to get a positive grade or to please the parents, or to improve one's career, then it means extrinsic motivation prevails. Intrinsic motivation shows when the student is stimulated to learn by his desire to improve his knowledge and to become a well-educated person. Therefore, intrinsic motivation means that a person's motivational stimuli are coming from within, while extrinsic motivation takes place when motivational stimuli are coming from the outside. We must admit that intrinsic motivation is very important for a successful development of professional competence.

Talking about the teaching profession itself, motivating factors might include:

- the need to make the teaching profession more attractive and provide for career development;

- the desire to promote the teachers' lifelong learning and engagement in continuing professional development;

- a demand for the professionalization of teaching;

- a desire to clarify the teacher's roles;

- the growing importance of school leadership;

- the need to assess the quality of teaching (Caena 18). 
As practice shows, the students' results in the process of FLT are different. And it is natural since, as shown by the research of Bloom and Carroll, if different people were taught the same amount of time by the same methods, the result would be still different. This is because all the students have different abilities, attitudes, aptitudes and a different level of motivation to learn and selfdevelop. It follows that a key condition of professional competence development would be the student's desire to work and study - his/her motivation.

The foreign language teacher plays an important role in increasing the students' motivation. Ur mentions three main ways to influence learners' motivation:

1. by taking every opportunity to show the learners how important it is for them to know English;

2. by fostering their self-image as successful language learners;

3. by proposing interesting classroom activities (Ur 11).

Motivation is extremely important for learning in class and for individual learning and self-development. Because the teacher is a model for his/her students, he/she should never stop learning and developing. A teacher should aim at developing his/her general knowledge, knowledge of the subject matter, improving his/her teaching skills, and getting to know the students' need and interests.

\section{CONCLUSIONS}

In the teaching-learning process, and in learning how to teach, the formation of professional competence is of vital importance. The foreign language teacher's professional competence is defined as a broad, multifaceted, integral concept, which determines the degree of mastery of the profession, manifested in the adequacy of solving professional tasks in the sphere of foreign language teaching. Among the key factors, which reflect the efficiency of the teacher's professional competence formation, are: knowledge of teaching subject, knowledge of methods of TFL, teaching practice, the personality factor, and self-education.

Interactive foreign language learning helps realize these factors, as interactive methods are powerful means of developing the students' fluency in language, allowing them to feel prepared for different situations in their future profession. 


\section{Works Cited}

Akhmad, Inna. "The main components of the pedagogical communication between teacher and students.” CCL Web: Advanced Education 2 (2014): n. pag. Web. 26 May. 2017.

Beebe, Leslie M. "Risk-taking and the language learner.” Classroom oriented research in second language acquisition. Ed. Seliger, W. and Long, M., 1983. Web. 17 November. 2016.

Caena, Francesca. Literature review. Teacher's core competences: requirements and development. European Commission, 2011.Web. 10 June. 2017.

Deakin Crick, Ruth. "Pedagogy for citizenship.” Getting involved: Global citizenship development and sources of moral values. Ed. F. Oser \& W. Veugelers. Rotterdam: Sense Publishers, 2008. Web. 08 June. 2017.

Dergunova, Nataliya. "Forming students-sociologists' professional competence in training math.” Math.Computer.Education. 1 (2006): 136-145. Web. 15 April 2015.

Doenyei, Zoltan. Motivational strategies in the language classroom. Cambridge: Cambridge University Press, 2001. Print.

Gardner, Robert. C. Social psychology and second language learning: the role of attitudes and motivation. Edward Arnold (Publishers) Ltd., 1985. Print.

Goncharenko, Semen. Ukrainian pedagogy dictionary, Kyiv: Lybid’, 1997. Print.

Liakopoulou, Maria. "The Professional Competence of Teachers: Which qualities, attitudes, skills and knowledge contribute to a teacher's effectiveness?” International Journal of Humanities and Social science, Vol 1, No 21 (Special Issue - December 2011): 66-78. Web. 10 May. 2017.

Mulder, Martin. “Conceptions of Professional Competence.” International Handbook of Research in Professional and Practice-based Learning. Ed. S. Billett, C. Harteis, H. Gruber. Dordrecht: Springer, 2014. Print.

Rivers, Wilga. "Interaction as the key to teaching language for communication." Interactive language teaching. Cambridge: Cambridge University Press, 1987. Web. 04 June. 2017.

Shyba, Alyona. "Analysis of the results of an experimental study on the formation of future translators’ professional competence.” Pedagogy and Psychology, 643 (2013): 188-195. Print.

Ur, Penny. A course in English Language teaching. Cambridge: Cambridge University Press, 2014. Print.

Wells, Gordon. Learning through interaction: The study of language development. Cambridge: Cambridge University Press, 1981. Print. 